\title{
カキ‘富有’の成熟に伴うカロテノイドの蓄積特性
}

\author{
新川 猛 ${ }^{1 *}$ ・鈴木哲也 ${ }^{2} \cdot$ 尾関 $\quad$ 健 $^{1} \cdot$ 加藤雅也 ${ }^{3 a} \cdot$ 生駒吉識 ${ }^{3}$ \\ ${ }^{1}$ 岐阜県農業技術センター 501-1152 岐阜市又丸 \\ 2 岐阜地域農業改良普及センター 500-8708 岐阜市司町 \\ 3 農業・食品産業技術総合研究機構果樹研究所カンキッ研究興津拠点 424-0292 静岡市清水区興津中町
}

\section{Characteristics of Carotenoid Accumulation during Maturation of the Japanese Persimmon 'Fuyu'}

\author{
Takeshi Niikawa ${ }^{1 *}$, Tetsuya Suzuki ${ }^{2}$, Takeshi Ozeki ${ }^{1}$, Masaya Kato ${ }^{3 a}$ and Yoshinori Ikoma ${ }^{3}$ \\ ${ }^{1}$ Gifu Prefectural Agricultural Technology Center, Gifu 501-1152 \\ ${ }^{2}$ Gifu Region Agricultural Development Center, Gifu 500-8708 \\ ${ }^{3}$ Department of Citrus Research, National Institute of Fruit Tree Science, National Agriculture and Food Research Organization (NARO), \\ Shizuoka 424-0292
}

\begin{abstract}
To investigate characteristics of carotenoid biosynthesis in the Japanese persimmon 'Fuyu' fruit during maturation, carotenoids and gene expression for phytoene synthase (DK-PSY), phytoene desaturase (DK-PDS), $\zeta$-carotene desaturase (DK-ZDS), lycopene $\beta$-cyclase (DK-LCYb), $\beta$-ring hydroxylase (DK-HYb), zeaxanthin epoxidase (DK-ZDS) and lycopene $\varepsilon$-cyclase (DK-LCYe) were analyzed. In the skin, lutein was the main carotenoid at the green stage. The level of gene expression of DK-LCYe was constant throughout the experimental period. In contrast, the level of carotenoid-biosynthetic enzymes with the exception of DK-LCYe was lower in the green stage than in the coloring stage. These findings suggested that during the green stage, DK-LCYe played an important role in carotenoid biosynthesis and was responsible for massive accumulation of lutein. In the coloring stage after October, $\beta$-cryptoxanthin $(\beta$-CRY) and zeaxanthin were mainly accumulated. At this stage, simultaneous increase of the gene expression for carotenoid-biosynthetic enzymes with the exception of DK-LCYe was observed. It was thought that the change in expression profile of the genes accelerated the accumulation of $\beta$-CRY and zeaxanthin in this stage. In the flesh, $\beta$-CRY and zeaxanthin were mainly accumulated in October. Lycopene was mainly accumulated in November. The lycopene accumulation was accompanied by a massive increase in expression of genes at the later stages of lycopene biosynthesis (DK-PSY, DK-PDS and DK-ZDS). This finding suggested that lycopene accumulation was caused by massive increase in the expression of genes at the later stages of lycopene biosynthesis.
\end{abstract}

Key Words : carotene, fruit color, pigment, real-time PCR, xanthophylls

キーワード：カロテン，果色，キサントフィル，リアルタイム PCR，色素

\begin{abstract}
緒言
カロテノイドは，高等植物では果実や花に蓄積すること によって黄色・オレンジ・赤色等を呈する色素である. カ ロテノイドは，抗酸化作用を持つことに加え，いくつかの 種類ではプロビタミン A 活性を持つ機能性成分であり, 近 年発ガン抑制効果（Nishino ら，2000）を始めとして多くの 生体調節機能に関して研究が進められている.

植物中のカロテノイド生合成系では，まず pyhtoene synthase（PSY）により無色のフィトエンが合成される. 次に

2006 年 7 月 14 日 受付. 2006 年 10 月 22 日 受理. 本報告の一部は平成 17 年園芸学会春季大会で発表した.

* Corresponding author. E-mail: niikawa-takeshi@pref.gifu.lg.jp

a 現在 : 静岡大学農学部
\end{abstract}

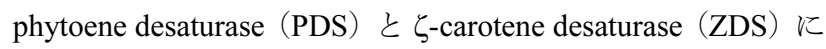
よりリコペンが合成される，その後合成経路は 2 つに分岐 し，一方では lycopene $\varepsilon$-cyclase（LCYe）により $\alpha$ 型カロテ ノイドである $\alpha$-カロテンやルテインが合成される.もら一 方では, lycopene $\beta$-cyclase (LCYb) により $\gamma$-カロテンを経 て $\beta$-カロテンが合成され， $\beta$-ring hydroxylase（HYb）によ り $\beta$-クリプトキサンチン $(\mathrm{CRY})$ ， ゼアキサンチンを順次 合成し，Zeaxanthin epoxidase (ZEP) によりビオラキサン チンが合成される（第1図），ビオラキサンチンからさらに 代謝が進むと植物ホルモンの一種であるアブシジン酸が合 成される。

植物種によってカロテノイド組成は異なり，アセロラで はフィトエンが，トマトではリコペンが多くの比率で含ま れており, $\beta$-CRYはミカンやカキ等の限られた果実に多く, 
Table 1 TaqMan probes used for the mRNA detection and primers used for the amplification of cDNAs by Real-Time PCR.

\begin{tabular}{|c|c|c|c|c|}
\hline Name & $\begin{array}{l}\text { Accession } \\
\text { number }\end{array}$ & TaqMan probe sequence & Primer sequence $^{z}$ & $\begin{array}{l}\text { Identity on the level of } \\
\text { Nucleotide Sequence with } \\
\text { Satsuma mandarin } \\
\text { (Accession No.) }\end{array}$ \\
\hline DK-PSY & AB258435 & TGCACCAGAATCACAGGCAACAACAGAG & $\begin{array}{l}\text { CTGTTGGATTGATGAGTGTTCCA } \\
\text { GCCAAGGCAGCATTGTAGACA }\end{array}$ & $85.3 \%(\mathrm{AB} 114648)$ \\
\hline DK-PDS & AB258434 & TGGCCCAAATCCCATTTAATGGTGC & $\begin{array}{l}\text { CTCAGGCCAAGTAAGCATTTCATTA } \\
\text { GCCGATTTGACTTTGCTGAAG }\end{array}$ & $86.2 \%(\mathrm{AB} 114649)$ \\
\hline DK-ZDS & AB258433 & ACCTTGCACTCGCATCCCCAGAAG & $\begin{array}{l}\text { ATGCAGATTCTCGTGTTTTGCA } \\
\text { AGCAATGAACCTTGTCCCTCA }\end{array}$ & $84.3 \%(\mathrm{AB} 072343)$ \\
\hline DK-LCYb & AB258436 & TTATGCCCAGGTGCCGTAATCGAGC & $\begin{array}{l}\text { TCCTGGAGTACCTGTGGAAGATATT } \\
\text { TCATCCTCTTCAATGCTCTTCACT }\end{array}$ & $82.9 \%(\mathrm{AB} 114652)$ \\
\hline DK-HYb & AB258438 & TGGACGAACATGTAGGCCATCCCA & $\begin{array}{l}\text { AGCCGGTCTTGGCATAACAG } \\
\text { CTGCAGCGACTCTCCTGAAGT }\end{array}$ & $88.0 \%(\mathrm{AB} 114653)$ \\
\hline DK-ZEP & AB258454 & CGGTGATGCAGCCAACCTGCATAA & $\begin{array}{l}\text { CATGGCTGCTTTGGAAGCTAT } \\
\text { GAAACACCGTCCACCAATCC }\end{array}$ & $81.9 \%(\mathrm{AB} 114654)$ \\
\hline DK-LCYe & AB258437 & CCTGCATGGGACAACAACATCAGTTCC & $\begin{array}{l}\text { CTCCCGAAGCAACAGTAGCAA } \\
\text { AACTACGAATGGGCAGAGTCTCAT }\end{array}$ & $89.4 \%(\mathrm{AB} 114655)$ \\
\hline
\end{tabular}

${ }^{\mathrm{z}}$ Sense Primers (Upper) and Antisense Primers (Lower).

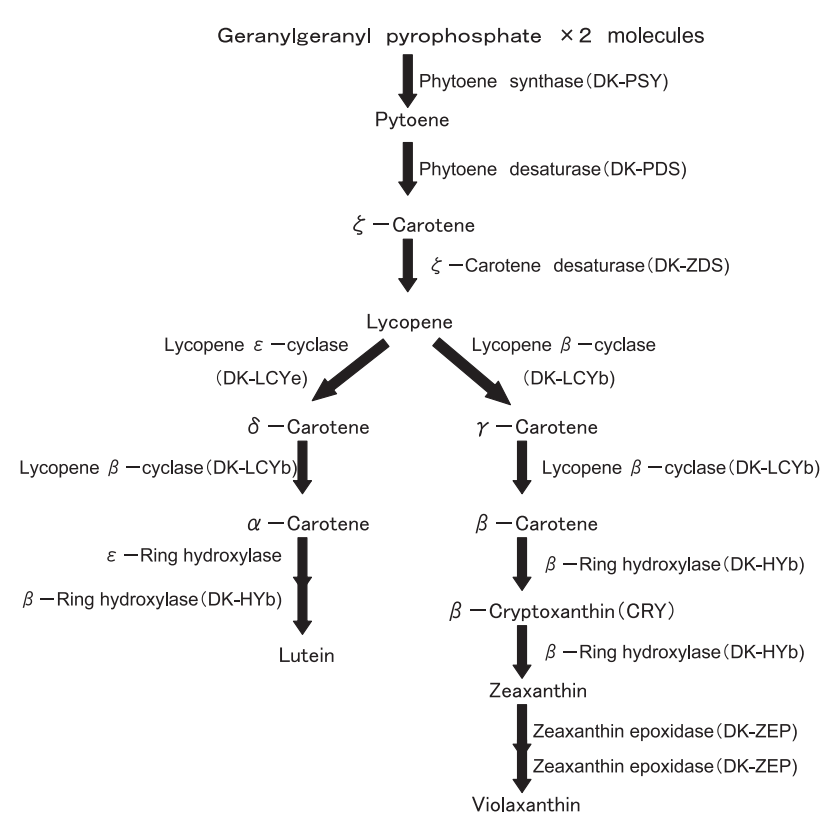

Fig. 1 Carotenoid biosynthetic pathway in plant. Seven cDNAs, DK-PSY，DK-PDS，DK-ZDS，DK-LCYb，DK-HYb，DKZEP, and DK-LCYe were cloned from Japanese persimmon 'Fuyu' and used for TaqMan probes for Real-Time PCR in this study.

供給源が限定される（Yanoら，2005）。トマトにおけるリ コペンの集積は, PSYの遺伝子発現が上昇するのに対して, LCYe や LCYb の遺伝子発現が上昇しないことから起こる (Giuliano ら, 1993; Ronen ら, 1999). カンキッでは, PSY 以下一連の遺伝子群の発現上昇が一斉に起こり, $\beta$-CRY や ビオラキサンチン等のキサントフィル類が多く蓄積する (Kato ら, 2004).
カキでは,リコペン含量が多くなると果皮の赤色が強くな り, 蓄積には秋季の気温と光が関与することが明らかとなっ ている (中條, 1982)。 また, 大部分の品種で果肉に蓄積す るプロビタミン A 活性を有するカロテノイドは，その $60 \%$ 以上が $\beta$-CRY であるとされている（田中ら，2002）。近年力 キの生産現場では, 着色が遅れたり黄色のまま収穫期を迎え る現象が多く認められ，産地ではその対応に苦慮している. この現象は, 気候温暖化の影響を受けているものと推察され るが，不明な点が多い：またカキには $\beta$-CRY が多く含まれ ていることから, 果肉中での含有量を高めることが可能とな れば, 嗜好品から健康増進のための果実といらイメージの転 換により, 新たな需要の喚起が期待できる. 本研究では, こ れらの問題を解決するための基礎的知見を得るため，力キ “富有”を材料とし，成熟に伴らカキのカロテノイド蓄積と 生合成に関与する遺伝子発現の特徵について明らかにした ので報告する.

\section{材料および方法}

平成 15 年に岐阜県農業技術センタ一植栽の 45 年生 “富 有’の果実を供試した。果実は，8月 1 日から収穫最盛期 の 11 月 15 日までの期間で毎月 1 日と 15 日に経時的に各 3 果ずつ採取した. よく水洗した後，へタと種子を取り除き， 果皮と果肉に分け，果皮色ならびに果肉色を測定した後， それぞれを実験に用いるまで $-80^{\circ} \mathrm{C}$ の超低温冷凍庫に保存 した。な拈，果皮と果肉は，ピーラーで剥いた厚さの組織 を果皮とし，それ以外を果肉として分類した。果皮色なら びに果肉色の測定は，色彩色差計（CR-200：ミノルタ）を 用い, 色相角度 $\left(\mathrm{H}^{\circ}\right)$ を測定した後, 富有用カラーチャー ト值に変換した. カロテノイドの定量は, Kato ら (2004) の方法に準じて，アセトン：メタノール（7:3）で抽出し 
$20 \% \mathrm{KOH} / \mathrm{MeOH}$ でケン化処理した後, C30 カラム (Carotenoid S-5 $4.6 \times 250 \mathrm{~mm}$ : YMC) を装着した HPLC-DAD（MD-910： Jasco）で行った. フィトエンおよびシスービオラキサンチ ンについては, ミカンの未熟果から抽出・精製したものを 標品として使用した.

第 1 図に示したカロテノイド生合成に関与する酵素の 内, phytoene synthase (DK-PSY), phytoene desaturase (DKPDS), $\zeta$-carotene desaturase (DK-ZDS), lycopene $\beta$-cyclase $(\mathrm{DK}-\mathrm{LCYb}), \beta$-ring hydroxylase (DK-HYb), zeaxanthin epoxidase (DK-ZEP), lycopene $\varepsilon$-cyclase (DK-LCYe) の cDNA 断 片を“富有”果実から Ready-To-Go First strand kit（アマシャ ムバイオサイエンス) を用いて合成した後, TA Cloning Kit （インビトロジェン）を用いてクローニングし，シーケン サー（ABI Prism Model 310 : アプライドバイオシステム） で塩基配列を決定した。 cDNA 産物は, ウンシュウミカン “宮川早生”由来の cDNA 産物との相同性を確認した後, Primer express（アプライドバイオシステム）を用いて TaqMan プローブとプライマーを設計・合成した（第 1 表）。カ キの果皮及び果肉からの全 RNA は, Hot Borate 法（Wan・ Wilkins, 1994）に準じて行い，ランダムへキサマーを用い た逆転写反応により cDNAを合成し，リアルタイム PCR (ABI Prism 7000:アプライドバイオシステム)により mRNA の発現量を求めた。な抏，mRNAの発現量は，ribosomal RNA を内在性コントロールとして用い, 初期テンプレート の濃度を補正して相対値として示した。

\section{結果}

\section{成熟に伴う果色の推移}

第 2 図にカキのカラーチャート值の推移を示した．果皮 色は，10月 1 日まではカラーチャート值 1 程度を示し，緑 色が強い未熟な時期であった. カラーチャート值は 10 月 15 日以降急速に高くなり，11月 15 日には 5.0 を越えて収 穫適期となった。果肉色は，果皮色活ど顕著ではなかった が，10月 15 日以降カラーチャート值が上昇した。

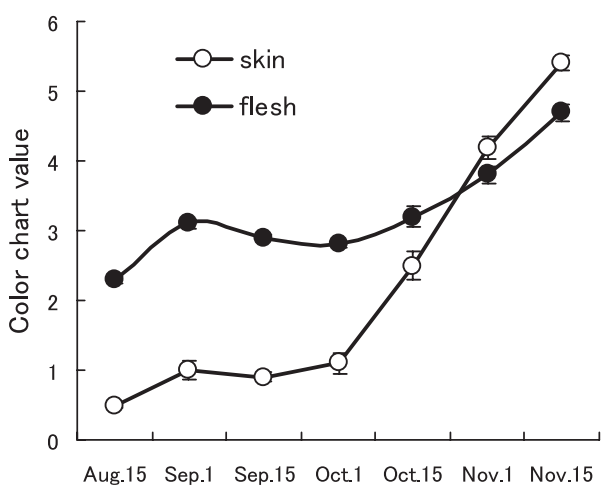

Fig. 2 Seasonal changes in the skin color on the equator portion and flesh color on the equator a cross section of Japanese persimmon 'Fuyu'. Vertical bars indicate SE $(n=5)$.
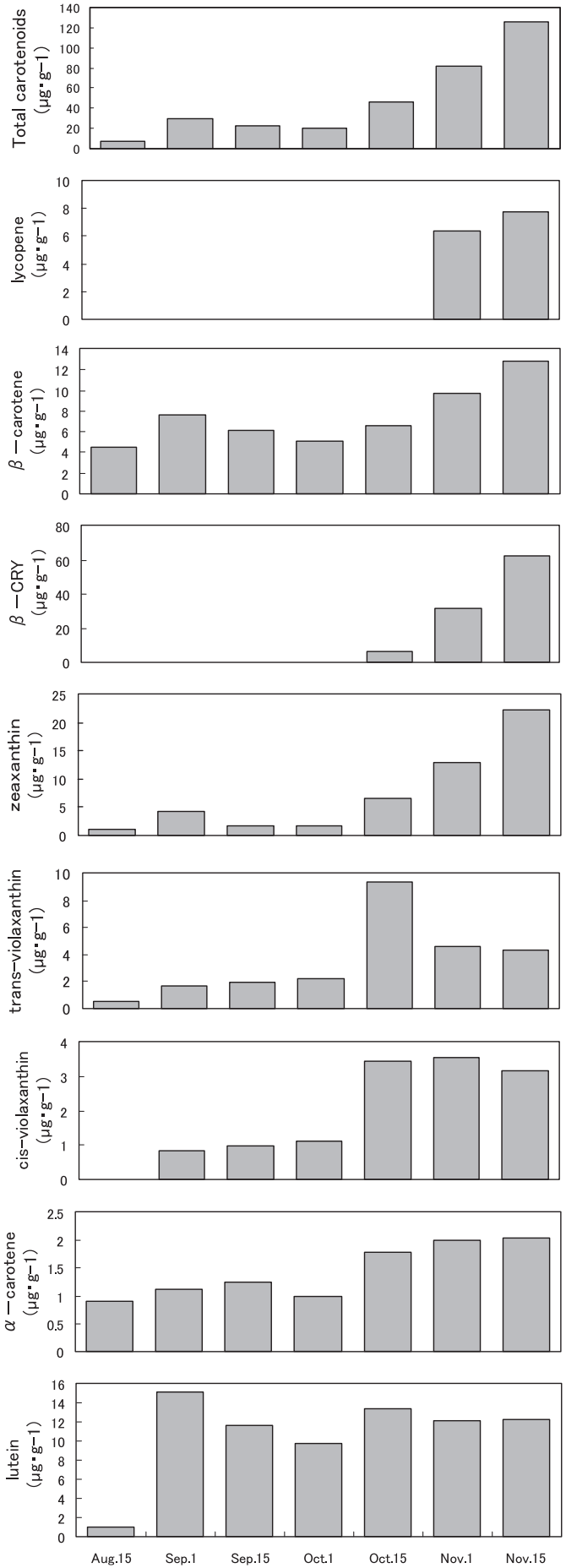

Fig. 3 Carotenoid concentration in the skin of Japanese persimmon 'Fuyu' during fruit maturation.

Phytoene was not detected. The value for total carotenoids was the sum of identified carotenoids (lycopene, $\beta$-carotene, $\beta$-CRY, zeaxanthin, trans-violaxanthin, cis-violaxanthin, $\alpha$ carotene and lutein). A sample of three fruits was crushed in a food processor, then stirred, and extracted using $5 \mathrm{~g}$. 

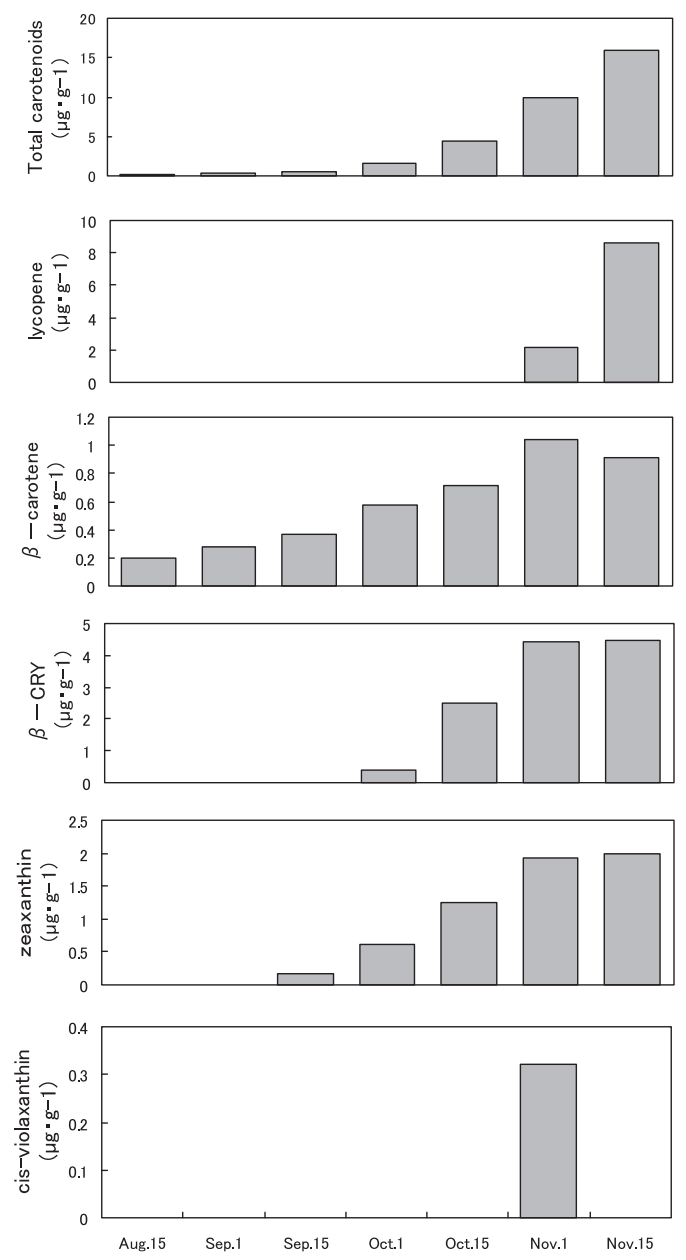

Fig. 4 Carotenoid concentration in the flesh of Japanese persimmon 'Fuyu' during fruit maturation.

Phytoene, cis-violaxanthin, $\alpha$-carotene and lutein were not detected. The value for total carotenoids was the sum of identified carotenoids (lycopene, $\beta$-carotene, $\beta$ CRY, zeaxanthin and trans-violaxanthin). A sample of three fruits was crushed in a food processor, then stirred, and extracted using $5 \mathrm{~g}$.
果皮におけるカロテノイド蓄積と mRNA レベルの推移

果皮では，10月 1 日以前の緑色期では， $\alpha$ 型カロテノイド であるルテインが蓄積しており, 全カロテノイド（フィトエ ン, $\zeta$-カロテン, リコペン, $\beta$-カロテン, $\beta$ - CRY, ゼアキ サンチン，ビオラキサンチン， $\alpha$-カロテン，ルテイン）の 内，50\%以上を占めていた。 10 月 15 日以降， $\beta$-CRY とゼ アキサンチン等の $\beta$ 型カロテノイドの蓄積が始まり, さら に 11 月以降リコペンが蓄積するにつれて, 全カロテノイド 中のルテインの比率は低下した. 11 月 15 日時点でのカロ テノイド組成は，ルテイン 9.7\% $\left(12.28 \mu \mathrm{g} ・ \mathrm{~g}^{-1}\right) ， \beta-\mathrm{CRY}$ $49.0 \%\left(62.23 \mu \mathrm{g} \cdot \mathrm{g}^{-1}\right) ，$ ゼアキサンチン $17.6 \%(22.33 \mu \mathrm{g} ・$ $\left.\mathrm{g}^{-1}\right)$ ，リコペン $6.1 \%\left(7.73 \mu \mathrm{g} ・ \mathrm{~g}^{-1}\right)$ であった（第3 図）。 カロテノイド生合成に関与する酵素遺伝子のmRNAレベル は，DK-LCYeでは全期間を通じて注涪一定に推移してい た．その他のカロテノイド生合成系遺伝子については, 10 月以前は低い発現であったが，10月 15 日以降は急激に増 加した（第 5 図）.

このように, DK-LCYeの発現レベルに明確な季節変化は 認められないが, 他の遺伝子の発現が 10 月以前には最低レ ベルにあったといら生理的状態から考元ると, 10 月以前に は着色期に比べ相対的に DK-LCYe の役割が大きく，その 結果として LCYeを経由して合成されるルテインの組成比 が高くなったと考光られた。一方，カロテノイドの活発な 蓄積が起こる 10 月 15 日には, DK-LCYe 以外の遺伝子の mRNA レベルの急激な上昇により，これらの酵素を経由し て合成される $\beta$-CRY やゼアキサンチンといったキサント フィル類が蓄積されたものと考光られた.

\section{果肉におけるカロテノイド蓄積と mRNA レベルの推移}

果肉では, 果皮色が緑色を示す 10 月 1 日以前には，活と んぞカロテノイドの蓄積が認められず，果皮の着色が始ま る 10 月 15 日以降に急激淁蓄積が始まった。 まず $\beta$-CRY と ゼアキサンチンの蓄積が始まり, 半月後の 11 月 1 日からは リコペンが蓄積した。リコペンは 11 月 15 日では全カロテ ノイドの内 $54 \%\left(8.6 \mu \mathrm{g} \cdot \mathrm{g}^{-1}\right)$ を占め, 最も高い比率で あった. $\beta$-CRY とゼアキサンチンの含有量は，11月 1 日以 降流とんぞ増加せず, このため 11 月以降のカロテノイド量

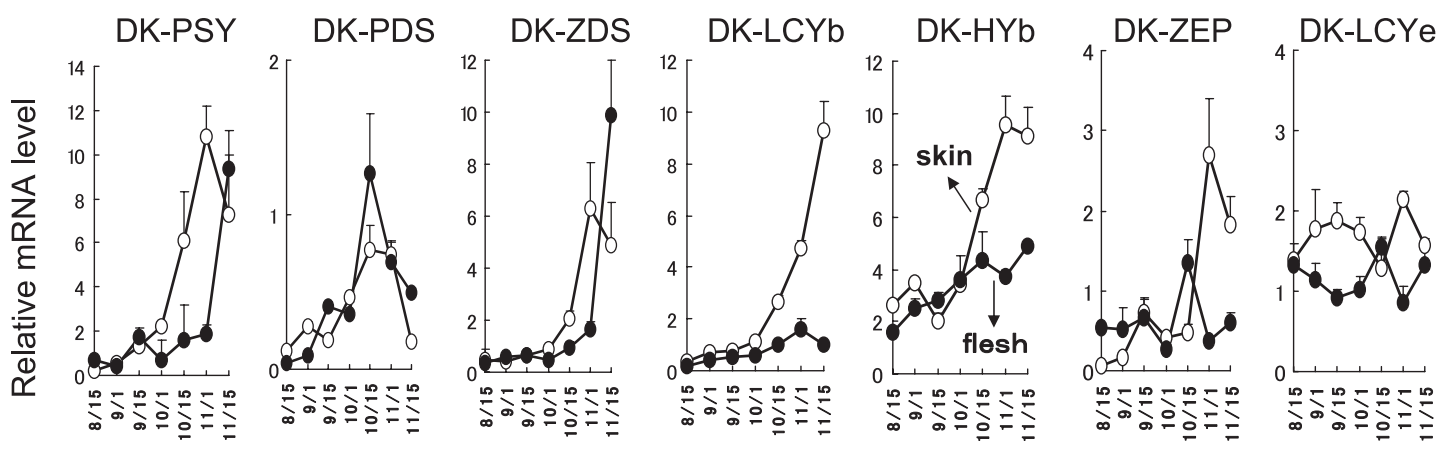

Fig. 5 Changes in mRNA levels for carotenoid biosynthetic genes in the skin and flesh of Japanese persimmon 'Fuyu' during fruit maturation. The levels of gene expression were normalized by the results of $18 \mathrm{~S}$ ribosomal RNA. Vertical bars indicate SE $(n=3)$. 
の増加は，汇とんどがリコペンによるものであった（第 4 図)。果肉のカロテノイド生合成系遺伝子の mRNAレベル をみると, DK-LCYe と DK-ZEP は全期間を通じて，注ぼ 定のレベルで推移したのに対して，その他のカロテノイド 生合成系遺伝子は, 成熟に伴って上昇する傾向を示した. 特に, 11 月以降はリコペンの上部に位置する DK-PSY, DKPDS，DK-ZDS の mRNA レベルは急激に上昇したが，果皮 の場合とは異なりリコペンより下部に位置する各酵素遺伝 子の mRNA レベルは漸増傾向にとどまった（第 5 図）。こ れらのことから，10月以降の mRNAレベルの上昇によっ て, キサントフィル類の蓄積が起こるが, 11 月以降には, リコペン生合成より上部に位置する酵素遺伝子のmRNAレ ベルの急激な上昇が，リコペンを特異的に蓄積させている ものと考えられた。

\section{考察}

中條・葦澤（1973）は“富有”の果皮の朱色ならびにリ コペンの発現に及ぼす温度の影響について採取果を用いて 調査したところ, その好適温度は 10 月中下旬には $25^{\circ} \mathrm{C}$, 11 月上中旬では $15^{\circ} \mathrm{C}$ と果実の成熟に伴い適温は低くなる こと, カロテン, クリプトキサンチン, ゼアキサンチン含 量は $25^{\circ} \mathrm{C}$ で最も増加したことを報告している. また, Ebert・ Gross（1984）は，‘Triumph’ では，リコペンは完熟直前に 急激に増加すると報告している. 今回の“富有”のカロテ ノイドの蓄積パターンでも, 平均気温の高い 10 月に $\beta$-CRY とゼアキサンチンが蓄積し, 成熟が進久気温の低下した 11 月にリコペンが蓄積しており，それらとほぼ一致した結果 が得られた。一方，カキの果皮中のルテインは，“四ッ溝” に拈いて未熟期から完熟期の間常に存在しており，特に未 熟期にその比率が高い（近・榛葉，1987）。今回 “富有”で も同様な結果が得られたことから，ルテインはカロテノイ ドの中で最初に蓄積し, 生育期間を通して常に一定量で保 持されているものと考光られた。 しか子その量は $10 \mu \mathrm{g} \cdot \mathrm{g}^{-1}$ を上回って扣り，カキの果皮を利用する際には，今後ルテ インの挙動について注目する必要がある。一方，ルテイン の蓄積にかわって, $\beta$-CRY とゼアキサンチンが蓄積を始め る変換点が 10 月 15 日前後であったが, ウンシュウミカン やトマトでも緑熟期から成熟期にかわる際に同様の変化が 認められる. ウンシュウミカンでは LCYbの発現量が増大 しかつ，LCYeの発現の低下が認められ（Kato ら，2004）, トマトでは LCYb と LCYe の両方の発現低下が認められて いる（Ronenら，1999）。カキでは，DK-LCYbの発現量の 増大は認められたものの, DK-LCYeの発現はほぼ一定で低 下していなかった，果実の種類によりこのような差が認め られる要因は不明であるが，各酵素の発現のバランスに よって蓄積するカロテノイドの種類が制御されているとい ら点は同じであった。 なお，カキの果皮中にルテインが多 く蓄積しているのは, DK-LCYeの発現量が低下しないこと が要因となっている可能性も考えられた.
果肉では, 果皮と比べて 11 月以降のリコペンの蓄積が特 異的に起こった。これはリコペン上流の酵素遺伝子の mRNAレベルの急激な上昇によりリコペンの蓄積に適した 発現パターンに変化したことに起因していると考えられ た.このように，果皮でキサントフィル類の蓄積が増大し ている時期に果肉ではリコペンが増加するといらことは, 果皮に比べて果肉の方が熟度が進んでいる可能性が考えら れる，現地では果皮の着色が遅れ，果肉のみが成熟するい わゆる「果肉先熟」現象が認められていることから, 今回 供試した果実にも同様の現象が起こっているのではないか と推察された。

カキはウンシュウミカンと並んで $\beta-C R Y の$ 貴重な供給源 である.カンキッでは，オレンジのように HYb の発現が高 くビオラキサンチンが集積するものと, ウンシュウミカン のようにHYbの発現が低くビオラキサンチンまで代謝が進 まないため $\beta$-CRY を集積するものとがあり，そのためウン シュウミカンで $\beta-C R Y$ が蓄積される要因は, HYb 遺伝子 の発現の低下によるものである（Kato ら，2004）。しかし， カキの果皮では，DK-LCYeを除く遺伝子群の一斉上昇に 伴って $\beta$-CRY と同時にビオラキサンチンも増加していく が，收穫直前になるとDK-ZEP の発現が低下し，ビオラキ サンチンの蓄積も停止した。 また，果肉では成熟に伴って DK-HYb が増加するのに対し DK-ZEP は増加せず， $\beta$-CRY とゼアキサンチンが蓄積するもののビオラキサンチンの蓄 積は認められない。このようにDK-HYbの発現が上昇して もビオラキサンチンの蓄積は起こらず， $\beta$-CRY が蓄積する ことは，オレンジやウンシュウミカンと異なっている. こ れは，カキはDK-ZEPの発現が低調で，ビオラキサンチン を蓄積しにくいタイプの果実であることが要因ではないか と考えられる.

近年増加傾向にある秋季の高温年では，果皮の着色遅延 や黄色のまま収穫期を迎えるといら現象を引き起こしてい る. 今回の研究からこのよらな現象は，高温によってキサ ントフィル類を蓄積しやすい条件が長く続き，リコペンを 蓄積する条件に移行しないことから引き起こされているも のと考えられる. 今後 $\beta-C R Y$ 等の機能性成分含量を高めた 果実生産を目指寸場合には, 当地に打ける 10 月の気象条件 である $20^{\circ} \mathrm{C}$ 程度の平均気温を長く維持するような栽培技 術確立に応用できるものと考吕らる。

著者らは，今回の“富有”に加えて成熟期の異なる ‘刀 根早生’ならびに ‘早秋’ に打いても同様な研究を行い, それぞれのカロテノイド蓄積パターンに加え，通常の果実 では検出されないフィトエンは，軟化が始まった完熟状態 の果実だけで蓄積が認められることから，カキのカロテノ イドは生合成系の下流から順に蓄積するものと推察した (新川ら，2005). 加光て両品種の比較においては, “刀根早 生’の方が相対的なカロテノイド生合成系酵素遺伝子の mRNA レベルが高いもののカロテノイドの蓄積量は少な く, ‘刀根早生’がカロテノイドを分解しやすい品種ではな 
いかとも推察した（新川ら，2005). Kato ら（2006）は, カ ンキッ果実のカロテノイド含量・組成の品種間差を決定す る要因にカロテノイド分解に関わる CitNCED (citrus 9-cisepoxycarotenoid dioxygenase）が関与していることを示唆し て抮り，カキに拈いてもカロテノイド生合成のさらに下流 のカロテノイド分解酵素の変動とその生成物由来のアブシ ジン酸の蓄積特性を明らかにすることで, カロテノイドを蓄 積する要因や品種間差の解明が可能となるものと思われた.

\section{摘 要}

カキ “富有”を用いて, 成熟に伴らカロテノイド蓄積と 生合成に関与する phytoene synthase (DK-PSY), phytoene

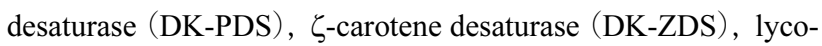
pene $\beta$-cyclase (DK-LCYb), $\beta$-ring hydroxylase (DK-HYb), zeaxanthin epoxidase (DK-ZEP), lycopene $\varepsilon$-cyclase (DKLCYe）の発現の特徵について明らかにした. 果皮では, 緑 色期の主要なカロテノイドはルテインであった。 これは DK-LCYeの遺伝子発現が全期間ほぼ一定に推移したのに 対して, 他の遺伝子は緑色期では最も低い発現レベルで あったため, 緑色期の LCYe の役割が着色期に比べて相対 的に大きくなり緑色期のルテインの蓄積に関与したためと 考えられた. 着色が始まる 10 月以降には, $\beta$-CRYならび にゼアキサンチンが蓄積した。 これはDK-LCYe 以外の遺 伝子発現の一斉上昇により, キサントフィル類が蓄積しや すい遺伝子発現パターンに変化したためと考えられた。果 肉では, 10 月に $\beta$-CRY ならびにゼアキサンチンが蓄積し, 11 月にはリコペンが蓄積した。 11 月のリコペンの蓄積は, リコペン生合成より上流に位置するDK-PSY, DK-PDS, DK-ZDS の急激な発現上昇によるものと考兄られた。

\section{引用文献}

中條利明. 1982. 富有カキ果実の発育ならびに品質に及ぼ 寸温度条件に関する研究. 香川大農学紀要. 37: 1-63. 中條利明・葦澤正義. 1973. 富有カキの果色に関する研究 III 採取果における朱色の発現に及ぼす温度の影響. 香川大農学報. 24: 129-135.

Ebert, G. and J. Gross. 1985. Carotenoid changes in the peel of ripening persimmon (Diospyros kaki) cv. Triumph. Phytochemistry $24: 29-32$.
Giuliano, G., G. E. Bartley and P. A. Scolnik. 1993. Regulation of carotenoid biosynthesis during tomato development. Plant Cell 5: 379-387.

Kato, M., Y. Ikoma, H. Matsumoto, M. Sugiura, H. Hyodo and M. Yano. 2004. Accumulation of carotenoids and expression of carotenoid biosynthetic genes during maturation in citrus fruit. Plant Physiol. 134: 824-837.

Kato, M., H. Matsumoto, Y. Ikoma, H. Okuda and M. Yano. 2006. The role of carotenoid cleavage dioxygenases in the regulation of carotenoid profiles during maturation in citrus fruit. J. Experiment. Botany 57: 2153-2164.

近 雅代・榛葉良之助. 1987. 四ッ溝柿の成熟, 貯蔵扣よ び干し柿加工中のカロチノイド組成の変化. 日食工誌. 34: $155-162$.

新川 猛・尾関 健・加藤雅也・生駒吉識. 2005. カキの カロテノイド蓄積及び生合成酵素遺伝子発現の品種間 差. 園学雑. 74 (別 2) : 356 .

Nishino, H., H. Tokuda, M. Murakoshi, Y. Satomi, M. Masuda, M. Onozuka, S. Yamaguchi, J. Takayasu, M. Okuda, F. Khachik, T. Narisawa, N. Takasuka and M. Yano. 2000. Cancer prevention by natural carotenoids. Biofacters 13: 89-94.

Ronen, G., M. Cohen, D. Zamir and J. Hirschberg. 1999. Regulation of carotenoid biosynthesis during tomato fruit development: expression of the gene for lycopene epsilon-cyclase is downregulated during ripening and is elevated in the mutant Delta. Plant J. 17: 341-351.

田中敬一・佐藤明彦・朝倉利員・村松 昇・山田昌彦. 2002. カキ果実に打ける $\alpha$-カロテン, $\beta$-カロテン, $\beta$-クリ プトキサンチン含量の品種間差異. 園学雑. 71（別 1) : 198.

Wan, C. Y. and T. A. Wilkins. 1994. A modified hot borate method significantly enhances the yield of high-quality RNA from cotton (Gossypium hirsutum L.). Anal Biochem. 223: 7-12.

Yano, M., M. Kato, Y. Ikoma, A. Kawasaki, Y. Fukazawa, M. Sugiura, H. Matsumoto, Y. Oohara, A. Nagao and K. Ogawa. 2005. Quantitation of carotenoids in raw and processed fruits in Japan. Food Sci. Tech. Res. 11: 13-18. 